\title{
Microdeletion syndromes
}

\author{
Chaitanya Datar \\ From International Conference on Human Genetics and 39th Annual Meeting of the Indian Society of \\ Human Genetics (ISHG) \\ Ahmadabad, India. 23-25 January 2013
}

Microdeletion syndromes are a group of disorders characterized by the deletion of a small chromosomal segment (usually $<5 \mathrm{Mb}$ in size) encompassing multiple disease genes, each potentially contributing to the disease phenotype independently. The mechanism of disease causation is usually due to haploinsufficiency of certain critical genes of that region. The genetic changes of these microdeletion syndromes are often not detected by the current band resolution using the routine or high resolution karyotyping (2-5 Mb) but require application of molecular cytogenetic techniques like Fluorescence in-situ Hybridization (FISH) or the latest array CGH technique.

FISH is now the standard technique for the diagnosis of common microdeletion syndromes like Prader Willi syndrome, Angelman syndrome, Velocardiofacial (DiGeorge) syndrome, William syndrome etc. It is also possible to diagnose rare syndromes like Wolf Hirschhorn syndrome, Smith Magenis syndrome etc by FISH if the degree of clinical suspicion is high. With the advent of chromosomal microarrays, detection of newer microdeletion syndromes and better characterization of existing syndromes has become possible.

Published: 21 January 2014

doi:10.1186/1755-8166-7-S1-113

Cite this article as: Datar: Microdeletion syndromes. Molecular

Cytogenetics 2014 7(Suppl 1):113.

Correspondence: dr.cdatar@gmail.com

Sahyadri Genetics, Unit of Sahyadri Hospitals, Barve Memorial Complex, J.M. Road, Pune, India

(C) 2014 Datar; licensee BioMed Central Ltd. This is an Open Access article distributed under the terms of the Creative Commons

C Biomed Central Attribution License (http://creativecommons.org/licenses/by/2.0), which permits unrestricted use, distribution, and reproduction in any medium, provided the original work is properly cited. The Creative Commons Public Domain Dedication waiver (http:// creativecommons.org/publicdomain/zero/1.0/) applies to the data made available in this article, unless otherwise stated.

Submit your next manuscript to BioMed Central and take full advantage of:

- Convenient online submission

- Thorough peer review

- No space constraints or color figure charges

- Immediate publication on acceptance

- Inclusion in PubMed, CAS, Scopus and Google Scholar

- Research which is freely available for redistribution 